\title{
THE IMPACT OF COVID-19 ON THE PRACTICE OF THE HUNGARIAN ADMINISTRATIVE PROCEDURAL LAW
}

\author{
Eszter Czibrik \\ PhD student, University of Miskolc, Faculty of Law, Institute of Public Law, Department of Administrative Law \\ 3515 Miskolc, Miskolc-Egyetemváros, e-mail: jogcze@uni-miskolc.hu
}

\begin{abstract}
In my study, I make an attempt to show how the special legal order has changed the regulation of administrative procedure in Hungary. Last year, a record number of decrees were issued in order to regulate the changed life situation as widely as possible. The administration could also not be an exception. In my study, I present the changes through examples. I deal in detail with the legal institution of the public hearing. I chose this because basically, in "peacetime", this legal institution would be inconceivable in practice without the personal presence of the clients, but in the changed life situation, the rules that apply to it cannot be fully applied. I supplement my remarks by supporting statistical data.
\end{abstract}

Keywords: COVID-19, administrative procedural law, Act CL of 2016 on the Code of General Administrative Procedure, special legal order

\section{Introduction}

Mask wearing, home office, quarantine, are all concepts that have been present in our daily lives for more than a year and a half. Hungary was perhaps in such a fortunate position that, seeing the other European states, we had some time to prepare until the situation worsened. In contrast to Italy, where the epidemic broke out in February 2020, only ad hoc decisions were made (Di Mascio et al., 2020). The coronavirus pandemic during this period has fundamentally changed people's daily lives, such as work, education and higher education, shopping habits, or even human relationships. In my study, I intend to limit this huge scope to administrative procedural law. My aim is to give a comprehensive picture of the changes in the regulation of the Hungarian administrative procedure from the beginning of the COVID-19 pandemic to the present day. In addition to the general rules of administrative procedural law, I would also like to give examples from sectoral legislation.

\section{At the time of the special legal order}

First of all, I would like to go into the presentation of domestic events and regulations, as I cannot go beyond national regulations and events due to content restrictions. You could say history, but the Government decided to declare the state of danger on March 11, 2020. I think the country as one man was afraid of the unknown situation. Then three o'clock in the afternoon, the Government Decree 40/2020 (11 March) on the declaration of state of danger came into force. The reason of declaration of the state of danger in the entire territory of Hungary was for the elimination of the consequences of the human epidemic endangering life and property and causing massive disease outbreaks, and for the protection of the health and lives of Hungarian citizens (Government Decree 40/2020). 
The Fundamental Law of Hungary distinguishes six types of special legal order, we can talk about the state of national crisis, the state of emergency, the state of preventive defence, the state of terrorist threat, the unexpected attack and the state of danger. Under our current Fundamental Law of Hungary, all special legal order can restrict fundamental rights. Decisions taken during the period of the special legal order may suspend the application of certain laws, except for the Fundamental Law of Hungary, or deviate from the provisions laid down in the law. However, this deviation can only take place with two condition, on the one hand only within the framework laid down in a cardinal act, and on the other hand the minimum of constitutionality must prevail even then (The Fundamental Law of Hungary, Article 53). In a state of danger, the Government may adopt decrees by means of which it may, as provided for by a cardinal Act, suspend the application of certain Acts, derogate from the provisions of Acts and take other extraordinary measures (The Fundamental Law of Hungary, Subsection (2) of article 53). In connection with the topic, I present the legal environment in the field of administrative procedure law, which differs from the usual in peacetime in state of danger.

The detailed rules of the state of danger are regulated by a cardinal act. The law declares that in the state of danger, it is possible to introduce rules that differ from the provisions of the Act on the Code of General Administrative Procedure by means of regulations. It can be seen that in this qualified period, the basic principle of the legislative hierarchy, according to which a lower level of legislation cannot contradict a higher level, can be disregarded. The reason for the breakthrough of the lex superiori derogat legi inferiori principle was to eliminate the consequences of a human epidemic causing a mass illness endangering the safety of life and property, and to protect the health and life of Hungarian citizens. The cardinal act allows for regulations other than those provided for in the Act CL of 2016 on the Code of General Administrative Procedure (hereinafter: the General Administrative Procedural Act.) and in sectoral legislation by means of regulations. It is possible, for example, to apply different from provisions concerning the determination of material and territorial competences, the administrative and other deadlines, the suspension of proceedings, the order of remedy, the rules of enforcement (Act CXXVIII of 2011, Subsection (3) of section 47). In the following, I will examine which of the cases mentioned was affected by the state of danger.

However, it should be noted that no detailed rules have been developed that would fundamentally change the norms of the general administrative procedure, as in contrast to civil and criminal proceedings that require essentially personal contact, the aspects of the administrative procedure are paper-based (or electronic) (Balázs and Hoffman, 2020). The proceedings were largely conducted according to the general, usual rules. However, even this part of the law cannot lack personal appearance (such as conducting an inspection, hearing a witness, receiving a completed ID card, or a public hearing, etc.), so the Government also had to regulate these procedural acts in order to avoid as much as possible personal contact.

In the following, I am going to deal with legal institutions based on personal participation and aimed at presenting the different rules laid down in the special legal order.

\subsection{The development of the regulation of authorisation requirement at the time of the special legal order}

In the Government Decree 191/2020 (V. 8.), it laid down diverse regulation for the procedures for issuing a permit by application. The regulation applied not only to decisions entitled to a permit, but also to all decisions on official approvals that allowed the client to carry out an activity or granted him the exercise of a right. The appendix of the Government Decree listed item by item the types of cases that were not covered by its scope, such as registration certificates, border police, expropriation 
procedure etc. In addition, the regulation allocate that proceedings excluded from the scope of the General Administrative Procedural Act also do not fall within its scope, such as infraction procedures, election procedures, tax and customs administration procedures etc (Act CL of 2016, Subsection (1) of section 8).

The regulation made the official authorization subject to notification in order to reduce the number of meetings between clients and administrators. The existence of the legal conditions and the notification communicated electronically, orally or by telecommunications within 8 days of the notification were sufficient to carry out the activity originally subject to the authorization procedure. The rule was different in the case of the assistance of a specialist authority, in that case the notification was communicated within 12 days (Government Decree, 191/2020). If the notification was not communicated, the notification shall be deemed to have been given on the day following the expiry of the time limit. The notification could be made via an electronic form using the Central WebPortal (Magyarorszag.hu), or in cases where the law did not only require an electronic form, it was possible to use this intention in the form of an e-mail following the expiry of the time limit. The provision in the interests of the client is evidenced by the section according to which the notification did not have to be accompanied by documents the acquisition of which would have imposed a disproportionate burden on the client due to the circumstances of the pandemic. At the same time, it had to declare in the notification the content of the documents not attached and the circumstance to which the incompleteness of the notification could be attributed.

\subsection{Public hearing}

In addition to the general rules of administrative procedural law, I also have to address the sectoral regulation too. First of all, the public hearing is mentioned, which, although not regulated by the General Administrative Procedure Act, but it is regulated by sectoral legislation. Regarding the public hearing, we find different regulations in Government Decree 143/2020 (IV. 22.). In administrative authority proceedings, the subject of a public hearing is essentially "to get to know the opinion of the public", the purpose of which is "to ensure that the public has access to information related to the subject matter of the administrative case and participates in decision-making" (Barabás et al., 2014). Basically, the legal institution used in each sectoral legislation to clarify the facts. For example, in the construction of clearways, in environmental impact assessment procedures, the environmental authority is obliged to hold a public hearing with the involvement of the transport authority and the builder in order to obtain the opinion of the public (Act CXXVIII of 2011, Subsection (1), (3) of section 9 and subsection (4) of section 5). If a similar public hearing took place during the state of danger, it could have been held without the personal appearance of those involved. In order to ensure the effectiveness of the public hearing, the authority could use, among other things, the local broadcasting service or the social media. The determining authority has published on its website all the information relevant for the participation of the parties concerned in the public hearing and the time limit within which they may make representations and submit questions (Government Decree, 143/2020).

During the state of danger, the said provision was also applied in practice, in connection with the procedure for amending the environmental permit for the construction of the section of the M2 clearway between Budapest and Vác In the report of the Government Office for Pest County, it was established that the date of the public hearing (27 May 2020) coincided with the existence of the state of danger situation, so it took place without the personal appearance of the persons concerned (Government Office for Pest County, 2020). In addition to the public hearing, other procedural acts requiring a personal appearance, such as an inspection, may only be ordered exceptionally during the state of danger. 
With this example, I wanted to show how the different regulations developed in relation to a legal institution where, in principle, personal appearance could not be dispensed with.

\subsection{E-administration in times of state of danger}

Despite many negative developments related to the coronavirus, some positive benefits can also be reported in the context of the pandemic. This is because the situation has created the widest possible eadministration. After all, those who were skeptical of this kind of administration were forced to take the opportunity. At the state of danger personal administration was basically recommended only in urgent cases, in all other cases, based on the information of government windows, e-administration was available and still available in the most common 750 cases, and the authorities encouraged them to use it. The aim was for as few people as possible to be in the customer areas at the same time, so that, for example, the completed documents did not have to be picked up in person in the government windows, but in the post office or in person by mail.

In the framework of the research, I also examined the statistical data on the use of the Central WebPortal (Magyarorszag.hu). It can be seen that the number of electronic administrations has increased significantly. In 2019, the number of electronic administrations - on a monthly basis - ranged from 360,715 to 586,611. That number, however, skyrocketed in 2020. Namely, in December 2020, the number of e-administrations reached 4,932,979. It can be seen that the state of danger has forced the citizens to have the widest possible electronic administration. And in the future, hopefully, this will mean that prospective clients will have more confidence in this more comfortable form of administration. It is important that the experience gained in the special legal order should be taken forward, with a view to extending online administration as widely as possible.

A number of regulation have been taken to simplify the administrative procedure. For example, if a client's driving license has expired, you can receive the new document in an automated process after the medical aptitude test, without personal administration. To do this, the client need to fill in an online statement, which can be found on the Central WebPortal (Magyarorszag.hu). In addition, in order to facilitate the situation of citizens, the validity of all official documents of Hungarian citizens in force in Hungary, which expire during the special legal order, has been extended to 60 days after the end of the special legal order (Government Decree, 500/2020).

\section{Afterword}

In my opinion, the special legal order legislation reflects the regulation the current administrative procedure. The number of general rules is very limited, but sectoral regulation is all the more diverse. The special legal order regulation is similar: the general rules were not really affected by the change, but the sectoral rules. An example is the creation of different rules for licencing procedures. Due to the special legal order, the validity of the building authority permit was extended by one year even in the absence of a separate application, if the permit expired within thirty days after the end of the special legal order.

In my view, in addition to the example, administrative acts requiring additional personal appearances could have been regulated by the government in order to further reduce personal contact, for example in the context of the production of evidence. After all, we can talk about several means of proof in connection with the production of evidence, which cannot preclude personal contact. For example the different rules on the duration of the state of danger did not affect the on-site inspection, the hearing of witnesses, the hearing or the case where the client makes a verbal statement on the content of an 
inaccessible document (Act CL of 2016 on the Code of General Administrative Procedure). In my opinion, in these cases as well, it would have been possible to introduce different regulations to minimize personal contact.

I think that the difficulty of the subject is given by the diversified regulation. Last year, a record number of government decrees were issued to regulate the changed life situation. As a final thought, I would like to conclude with the following: when choosing the topic of a study, we should try to select the most current one. However, in my view, on behalf of many, I confidently state the opinion that we would like to see this topic if it were less timely and topical.

\section{References}

[1] Di Mascio, F., Natalini, A., Cacciatore, F. (2020). Public administration and creeping crisis: Insights from COVID-19 pandemic in Italy. The American Review of Public Administration, 50(6-7), 621-627. p. 625. https://doi.org/10.1177/0275074020941735

[2] Section 1 of Government Decree 40/2020 (11 March) on the declaration of state of danger

[3] Article 53 of The Fundamental Law of Hungary

[4] Subsection (2) of article 53 of The Fundamental Law of Hungary

[5] Subsection (3) of section 47 of Act CXXVIII of 2011

[6] Balázs, I., Hoffman, I. (2020.21.): Közigazgatás és koronavírus - a közigazgatási jog rezilienciája vagy annak bukása? MTA Law Working Papers. https://jog.tk.hu/mtalwp/kozigazgatas-koronavirus-idejen-a-kozigazgatasi-jog-rezilienciaja (2021. 08. 25.)

[7] Subsection (1) of section 8 of Act CL of 2016

[8] Sebsection (9) of section 5 of Government Decree 191/2020 (8 May)

[9] Barabás, G., Baranyi, B., Kovács, A. Gy. (Eds.) (2014). Nagykommentár a közigazgatási eljárási törvényhez. Budapest, Wolters Kluwer Hungary Kft.

[10] Subsection (1), (3) of section 9 and subsection (4) of section 5 of Act CXXVIII of 2011

[11] Subsection (2) - (4) of section 4 of Government Decree 143/2020 (22 April)

[12] Government Office for Pest County (PE/KTFO/282-84/2020)

[13] Subsection (1) of section 1 of Government Decree 500/2020 (13 November)

[14] Subsection (1) of section 64 of Act CL of 2016 on the Code of General Administrative Procedure 